\title{
Health Services Vocational School Students' Opinions About Smartphone Usage and The Relationship Between Internet Addiction
}

\author{
Arslan SAY ${ }^{1 *}$, Demet ÇAKIR ${ }^{2}$ \\ ${ }^{1}$ Sabuncuoğlu Şerefeddin Vocational School of Health Services, Amasya University, Amasya, Turkey \\ * Corresponding Author : Email: arslan.say@ amasya.edu.tr ORCID: 0000-0002-1695-5624 \\ ${ }^{2}$ Sabuncuoğlu Şerefeddin Vocational School of Health Services, Amasya University, Amasya, Turkey \\ Email: demet.cakir@ amasya.edu.tr ORCID: 0000-0003-4794-516X
}

\section{Article Info:}

DOI: $10.22399 /$ ijcesen. 987432

Received: 26 August 2021

Accepted: 26 November 2021

\section{$\underline{\text { Keywords }}$}

Smartphone

Internet addiction

Student

\begin{abstract}
:
In this research, it was aimed to determine the students' smartphone and internet addiction levels and related factors. The universe of the research consists of 825 students studying at the Vocational School of Health Services of a university in the 2015-2016 academic year. Of the 825 students, 668 students who agreed to participate in the research constituted the sample of the study. The data of this research were collected with Internet and Smartphone Usage Information Form, Internet Addiction Scale (IAS), and Smartphone Addiction Scale-Short Form (SASF). The average age of the students is $20.2 \pm 1.12$, and $44.3 \%(n=298)$ of them mostly connect to the internet from home. The mean scores obtained from the scales were $38.41 \pm 16.26$ in IAS and 28.09 \pm 11.93 in SASF. A significant difference was determined between IAS and gender, monthly expenditure, daily and weekly internet use, and purpose of using the internet $(\mathrm{p}<0.05)$. A significant difference was determined between SASF and age, daily and weekly internet use, and purpose of using the internet $(\mathrm{p}<0.05)$. A moderately significant positive correlation was found between the IAS and the mean SASF score $(\mathrm{r}=0.515, \mathrm{p}=0.000)$. The level of internet addiction was found to be high in 20-year-old males, staying at home, and students with a monthly expenditure of 650 TL or more. Smartphone addiction was found to be high in 20-yearold women, those living with their relatives, and students whose monthly expenditure was between 250-449 TL. According to the average score obtained from the Internet addiction scale, it was determined that the students participating in the study were addicted without symptoms. In addition, according to the correlation analysis, as internet addiction increases, smartphone addiction also increases. It is thought that students' internet and smartphone use may affect their social interactions and prevent students from using emotional and cognitive processes effectively.
\end{abstract}

\section{Introduction}

Since The iPhone was introduced to market by Steve Jobs in 2007, smartphones have been gained power with a rapid development. This rapid development has influenced to a large number of smartphone users worldwide. Recent statistics indicate that approximately two billion people in the world use smartphones to communicate, browse the Internet or simply play video games [1].
Nomophobia, which is considered the phobia of the 21st century [2], means for NO Mobile Phone PHOBIA and in clinical psychology defined as an irrational fear such as inability to reach a mobile phone or not being able to communicate with a mobile device [2]. Individuals exhibiting nomophobic behaviours worry when they forget to take their mobile phones with them, battery is out of charge or be in no network coverage area. This anxiety state negatively affects the concentration of the individual to perform daily activities [3]. 
Although nomophobia is not included in the field of clinical psychology, worldwide studies have been conducted on the prevalence of nomophobia among individuals. According to the results of a study conducted by SecurEnvoy (2012), which evaluated the nomophobia status of working people in their business life's, the number of mobile phone users exhibiting nomophobic behaviours increased in the last four years. As stated by this research, $66 \%$ of smartphone and mobile phone users expressed that they were worried and afraid at the thought of losing their phones [4].

The use of the Internet on a global scale started to become widespread in the 1990s and has deeply affected our lives. The rapid spread of smartphones after 2010 has made the use of the internet even more common. The widespread use of the Internet has increased its use, especially among students. According to the research, it has been determined that students who are internet literate and good at use of internet perform better academically [5]. However, it is known that internet have some negative effects. As a result of not being able to control excessive internet use, it has been observed that internet addiction occurs by causing severe problems with the environment in daily life. The effect of this such addiction can be compared to alcoholism or compulsive gambling [6].

With the continuous increase in internet and smart phone use, it is thought that this new technology affects the habits, behaviours and emotions of individuals, and it is necessary to examine the relationship between internet and smart phone use, especially the prevalence of nomophobia in the younger generation. Besides, it has become important to evaluate the relationship between university students' smartphone use and internet addiction.

\section{Materials and Methods}

\subsection{Type of the Study}

The research was conducted in a cross-sectional descriptive type in order to determine the opinions of student at vocational school of health services on smart phone use and internet addiction.

\section{Location of the Study Conducted}

The universe of the research consists of students studying at the Vocational School of Health Services (VSHS) of a university in the spring semester of the 2015-2016 academic year. There are 825 students enrolled in VSHS in the spring semester of the 2015-2016 academic year. By using the simple random sampling technique to determine the sample, 668 students who agreed to participate in the research were reached. The data were collected between 01-31 March 2016. After the purpose of the research was explained to the students in the classroom and their informed consent was obtained, questionnaire forms were applied to those who agreed to participate in the study. Personal Information Form, Internet and Smartphone Usage Information Form, Internet Addiction Scale and Smartphone Addiction ScaleShort Form were used as data collection tools.

\subsection{Data Collection Tools}

Personal Information Form: This form, which was developed by the researchers in accordance with the literature [7,8], consists of a total of 4 questions including the informative characteristics of the students (gender, age, residence during the study period, monthly expenditure amount).

Internet and Smartphone Usage Information Form: This form, which was developed by the researchers in accordance with the literature $[9,10]$, consisted of a total of 4 questions including the internet and smart phone usage characteristics of the students (where the use of internet started, daily and weekly internet usage time, internet usage reason).

Internet Addiction Scale (IAS): The scale was developed by Young in 1996 [11], The Turkish validity and reliability of whom was performed by Bayraktar in 2001. The scale is a 6-point Likerttype scale consisting of 20 questions. It was counted "never" as 0 points, "rarely" as 1 point, "occasionally" as 2 points," often" as 3 points, "very often" as 4 points and" always" as 5 points. There is no reverse scored item in the scale. The highest score that can be obtained from the scale is 100 and the lowest score is 0 . By summing up the scores obtained as a result of the survey, users who score 50 points or less are classified as "No Symptom", 50-79 points as "Limited Symptom", and 80 points and above as "Pathological Internet User". The high scores obtained from the scale indicate that internet addiction is high. The scale has a single factor, and the Cronbach Alpha reliability coefficient was calculated as 0.89 in the study in which Turkish validity and reliability were conducted [7]. In this study, the Cronbach's Alpha value of the scale was found to be 0.89 .

Smartphone Addiction Scale (SAS)-Short Form: The Scale which developed by Kwon and his friends [13] and whom of Turkish validity and reliability was performed by Noyan and his friends [15]. The scale has a 6-point Likert type structure consisting of 10 questions. It was taken "strongly disagree" as 1 point, "disagree" as 2 points, "partially disagree" 3 points, "partially agree" as 4 points, "agree" as 5 points, "strongly agree" as 6 points. The highest score that can be obtained from the scale is 60 and the lowest score is 10 . An 
increase in the scores obtained from the scale indicates addiction risk increase. The scale has one factor and has no sub-dimensions. The Cronbach's Alpha coefficient of internal consistency and concurrent validity of the original form was 0.91 . In this study, the Cronbach's Alpha value of the scale was found to be 0.87 .

\subsection{Statistical Analysis}

Statistical evaluation of the data was done with SPSS 22.0 for Windows in computer environment. In the analysis of data, in addition to descriptive statistical criteria (mean, standard deviation, minimum and maximum values and percentiles), Chi-Square, OneWay Anova and t tests were used to compare the scale score with the variables. The homogeneous distribution of the variables was analysed by Kolmogrov Smirnov. Tamhane T2 test was used in the post hoc analysis of groups with 3 and more than 3 variables. When the variables were not homogeneously distributed, Mann Whitney U test was used and otherwise the t test was used. Statistical significance was accepted as $\mathrm{p}<0.05$.

\subsection{Ethical Aspect of the Research}

Application permission was obtained from the VSHS Directorate of the university where the study was conducted, and written informed consent was taken from the students participating in the study.
The study was conducted in accordance with the Principles of the Declaration of Helsinki.

\section{Results}

While $76.8 \%(n=517)$ of the students within the scope of the research were women, 23.2\% $(n=156)$ were men. Moreover, the average age of the students is $20.2 \pm 1.12$, and students of $23.2 \%$ $(n=156)$ are 20 -year-old. $45.2 \% \quad(n=304)$ of the participants stated that they resided with their families, and $27.9 \% \quad(n=188)$ of them stated that their monthly expenditure at education season was between 450-649 TL. In the comparison of the socio-demographic characteristics of the students participating in the research with the total score they got from the SAS and IAS, it was determined that there was a significant difference between gender \& monthly expenditure amount and ISI, and between age variable and SAS $(\mathrm{p}<0.05)$. It was seen that there is no significant difference between the other variables and the scales $(p>0.05)$. According to the post hoc analysis, the significance between the IAS and the amount of monthly expenditure existed in students whose monthly expenditures are between 50-249 TL and $650 \mathrm{TL}$ and above; The significance between SAS and the age variable was found to be between 20 years old and 23 years old and over students (Table 1).

Table 1: Comparison of Students' Total Scores of Internet Addiction (IAS) and Smartphone Addiction (SAS) Scales and Sociodemographic Characteristics $(n=668)$

\begin{tabular}{|c|c|c|c|c|c|c|c|}
\hline & \multirow[b]{4}{*}{$\mathbf{n}$} & \multirow{4}{*}{$\%$} & \multirow{3}{*}{\multicolumn{2}{|c|}{ IAS }} & \multirow{3}{*}{\multicolumn{2}{|c|}{ SAS }} \\
\hline & & & & & & & \\
\hline & & & & & & & \\
\hline & & & & $\mathrm{X} \pm \mathrm{SS}$ & $\mathrm{p}$ & $\mathrm{X} \pm \mathrm{SS}$ & $\mathrm{p}$ \\
\hline Gender & Female & 517 & 76,8 & $37.67 \pm 16.08$ & \multirow{2}{*}{$-2.127 * / 0.034$} & $28.41 \pm 12.17$ & \multirow{2}{*}{$1.537 * / 0.199$} \\
\hline \multirow{6}{*}{ Age } & $\begin{array}{l}\text { Male } \\
18\end{array}$ & $\begin{array}{l}156 \\
104\end{array}$ & 23,2 & $\begin{array}{l}\mathbf{4 0 . 8 2} \pm \mathbf{1 6 . 6 7} \\
39.27 \pm 13.48\end{array}$ & & $\begin{array}{l}27.01 \pm 11.05 \\
29.93 \pm 12.47\end{array}$ & \\
\hline & $\begin{array}{l}10 \\
19\end{array}$ & 154 & 22.9 & $37.77 \pm 15.56$ & \multirow{5}{*}{$1.182 * * / 0.317$} & $28.40 \pm 11.86$ & \multirow{5}{*}{$3.347 * * / 0.005$} \\
\hline & 20 & 156 & 23.2 & $40.33 \pm 15.79$ & & $30.01 \pm 11.89^{a}$ & \\
\hline & 21 & 97 & 14.4 & $37.89 \pm 14.77$ & & $26.12 \pm 10.77$ & \\
\hline & 22 & 43 & 6.4 & $39.65 \pm 17.79$ & & $28.05 \pm 11.44$ & \\
\hline & 23 and above & 119 & 17.7 & $35.89 \pm 20.04$ & & $25.16 \pm 12.06^{\mathrm{a}}$ & \\
\hline \multirow{6}{*}{$\begin{array}{c}\text { Residence } \\
\text { During The } \\
\text { Study } \\
\text { Period }\end{array}$} & Home alone & 22 & 3.3 & $35.45 \pm 17.62$ & \multirow{6}{*}{$1.397 * * / 0.223$} & $29.77 \pm 17.12$ & \multirow{6}{*}{$1.627 * * / 0.151$} \\
\hline & Home with & 72 & 10.7 & $42.31 \pm 16.98$ & & $28.63 \pm 10.16$ & \\
\hline & friends & 304 & 45.2 & $38.25 \pm 17.65$ & & $27.50 \pm 12.06$ & \\
\hline & With family & 30 & 4.5 & $41.37 \pm 16.84$ & & $32.83 \pm 15.68$ & \\
\hline & With relatives & 207 & 30.8 & $37.24 \pm 13.19$ & & $28.39 \pm 11.05$ & \\
\hline & $\begin{array}{l}\text { Dormitory } \\
\text { Hostel/hotel }\end{array}$ & 38 & 5.6 & $38.00 \pm 16.75$ & & $25.42 \pm 11.21$ & \\
\hline \multirow{4}{*}{$\begin{array}{l}\text { Monthly } \\
\text { Expenditur } \\
\text { e Amount }\end{array}$} & $50-249 \mathrm{TL}$ & 169 & 25.1 & $36.76 \pm 15.86^{\mathrm{a}}$ & \multirow{4}{*}{$3.512 * * / 0.015$} & $27.95 \pm 11.69$ & \multirow{4}{*}{$1,227 * * / 0.299$} \\
\hline & $250-449 \mathrm{TL}$ & 188 & 27.9 & $37.51 \pm 15.23$ & & $29.23 \pm 11.30$ & \\
\hline & 450-649 TL & 154 & 22.9 & $37.57 \pm 15.12$ & & $26.75 \pm 12.67$ & \\
\hline & 650 TL ve üzeri & 162 & 24.1 & $41.96 \pm 18.36^{\mathrm{a}}$ & & $28.18 \pm 12.12$ & \\
\hline
\end{tabular}

*Indenpendent Sample T Test was used

** One Way Anova Test is used

***a: There is a difference between the groups with the same letter with the scale grand total 
At Table 2, in which the internet usage information is evaluated, it was determined that $44.3 \%(n=298)$ of the students are connected to the internet at home, $35.2 \%(n=237)$ use the internet for more than 241 minutes daily, $70.9 \%(n=477)$ use internet regularly everyday of week, $50.7 \%(n=341)$ use the internet to follow the events. In the comparison of the total scores obtained from the IAS and SAS of the students participating in the research and their internet usage characteristics, it was determined that there was a significant difference between the total score averages of the IAS and SAS scales for daily and weekly internet and internet use $(p<0.05)$. It is seen that there is no significant difference between the other variables and the scales ( $p>0.05)$. According to the post hoc analysis, the significance between IAS and daily internet use exists in those who use the internet less than 30 minutes a day and those who use the internet between 121-240 minutes and less than 30 minutes and more than 241 minutes; In SAS, on the other hand, it was found that this significance exist in those who used less than 30 minutes and more than 241 minutes (Table 2).

Table 2: Evaluation of Students' Total Scores of Internet Addiction (IAS) and Smartphone Addiction (SAS) Scales and Internet Usage Knowledge $(n=668)$

\begin{tabular}{|c|c|c|c|c|c|c|c|}
\hline & \multirow[b]{2}{*}{$\mathbf{n}$} & \multirow{2}{*}{$\%$} & \multicolumn{2}{|c|}{ IAS } & \multicolumn{2}{|c|}{ SAS } \\
\hline & & & & $\mathrm{X} \pm \mathrm{SS}$ & $\mathrm{p}$ & $\mathrm{X} \pm \mathrm{SS}$ & $\mathrm{p}$ \\
\hline \multirow{7}{*}{$\begin{array}{l}\text { Internet } \\
\text { connection } \\
\text { location }\end{array}$} & Home & 298 & 44.3 & $38.20 \pm 17.05$ & \multirow{7}{*}{$0,182 * / 0.982$} & $27.28 \pm 11.35$ & \multirow{7}{*}{$1.663 * / 0.127$} \\
\hline & School & 24 & 3.6 & $38.79 \pm 16.41$ & & $32.46 \pm 17.75$ & \\
\hline & Internet cafe & 9 & 1.3 & $35.53 \pm 18.42$ & & $21.22 \pm 13.12$ & \\
\hline & Library & 6 & 0.9 & $37.83 \pm 22.29$ & & $24.17 \pm 11.75$ & \\
\hline & Mobile phone & 187 & 27.8 & $39.18 \pm 16.53$ & & $28.45 \pm 11.80$ & \\
\hline & Acquaintance's place & 12 & 1.8 & $40.09 \pm 25.28$ & & $27.00 \pm 14.91$ & \\
\hline & Dormitory & 137 & 20.4 & $37.82 \pm 12.75$ & & $29.31 \pm 11.59$ & \\
\hline \multirow{4}{*}{$\begin{array}{l}\text { Daily } \\
\text { internet } \\
\text { usage }\end{array}$} & less than $30 \mathrm{~min}$. & 47 & 7.0 & $28.78 \pm 16.03^{\mathrm{ab}}$ & \multirow{4}{*}{$30.408 * / 0.000$} & $22.66 \pm 10.94^{\mathrm{a}}$ & \multirow{4}{*}{$18.618 * / 0.000$} \\
\hline & $31-120 \mathrm{~min}$. & 219 & 32.5 & $32.32 \pm 14.01$ & & $24.39 \pm 9.65$ & \\
\hline & $121-240 \mathrm{~min}$. & 170 & 25.3 & $40.72 \pm 15.88^{\mathrm{a}}$ & & $29.85 \pm 12.24$ & \\
\hline & Above $241 \mathrm{~min}$. & 237 & 35.2 & $44.24 \pm 15.82^{b}$ & & $31.32 \pm 12.53^{\mathrm{a}}$ & \\
\hline \multirow{4}{*}{$\begin{array}{l}\text { Weekly } \\
\text { internet } \\
\text { usage }\end{array}$} & 1 day a week & 29 & 4.3 & $29.07 \pm 12.64 \mathrm{ab}$ & \multirow{4}{*}{$5.919 / 0.001$} & $22.17 \pm 9.98^{\mathrm{ab}}$ & \multirow{4}{*}{$4.909 * / 0.002$} \\
\hline & 2-3 days a week & 67 & 10.0 & $33.75 \pm 12.63 \mathrm{c}$ & & $25.61 \pm 10.41^{\mathrm{c}}$ & \\
\hline & 4-5 days a week & 100 & 14.9 & $38.36 \pm 18.80 \mathrm{a}$ & & $26.77 \pm 11.54^{\mathrm{a}}$ & \\
\hline & $\begin{array}{l}\text { Every day of the } \\
\text { week regular }\end{array}$ & 477 & 70.9 & $39.62 \pm 16.07^{\mathrm{bc}}$ & & $29.07 \pm 12.16^{\mathrm{bc}}$ & \\
\hline \multirow{6}{*}{$\begin{array}{l}\text { Purpose of } \\
\text { using the } \\
\text { internet }\end{array}$} & Following events & 341 & 50.7 & $36.76 \pm 14.84^{\mathrm{a}}$ & \multirow{6}{*}{ 3.474/0.004 } & $27.73 \pm 11.53^{\mathrm{a}}$ & \multirow{6}{*}{$5.500 * / 0.000$} \\
\hline & E-mail/instant & 115 & 17.1 & $40.77 \pm 16.86$ & & $28.57 \pm 12.18$ & \\
\hline & messaging & 14 & 2.1 & $46.21 \pm 18.05$ & & $27.86 \pm 14.12$ & \\
\hline & Playing online games & 86 & 12.8 & $42.29 \pm 14.27^{\mathrm{a}}$ & & $33.22 \pm 12.82^{\mathrm{a}}$ & \\
\hline & Surfing on internet & 10 & 1.5 & $44.40 \pm 21.05$ & & $29.90 \pm 8.93$ & \\
\hline & $\begin{array}{l}\text { Online shopping } \\
\text { Doing homework }\end{array}$ & 107 & 15.9 & $36.40 \pm 19.53$ & & $24.45 \pm 10.83$ & \\
\hline
\end{tabular}

*One Way Anova Test is used

**a-c: There is a difference between the groups with the same letter with the scale grand total

According to the correlation analysis performed with the double-tailed hypothesis method to determine the relationship between IAS and SAS, it was determined that there was a moderate, positive and significant relationship between the scales $(\mathrm{r}=0.515 ; \mathrm{p}=0.000) . \quad(\mathrm{p}<0,05) \quad($ Table 3$)$ (Graphic 1). It was determined that as internet addiction of students increased, smart phone addiction increased, and as smart phone addiction increased, internet addiction increased.
The data obtained in this study, which was conducted to determine the factors related to smartphone and internet addiction level in students, were discussed in line with the literature. In the study, it was determined that as the internet addiction level of the students increased, the smart phone addiction increased. When the studies on internet and smartphone addiction are evaluated, studies on different groups of university students are encountered. It is thought that this study will contribute to the knowledge in the literature.

\section{Conclusions}


Table 3: Correlation and Graph of Internet Addiction Scale (IAS) and Smartphone Addiction Scale (SAS)

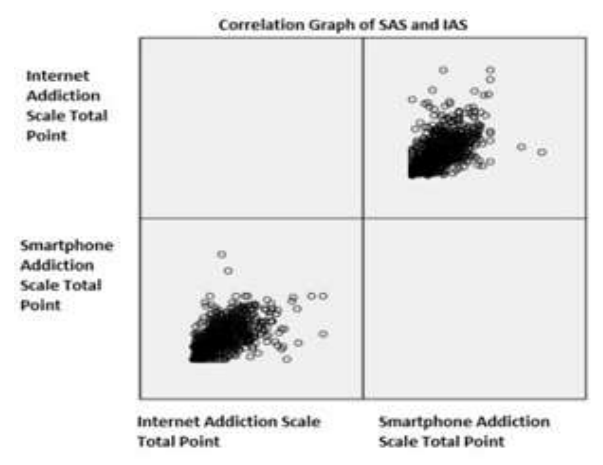

\begin{tabular}{|l|l|l|l|}
\hline \multicolumn{2}{|l|}{} & IAS & SAS \\
\hline IAS & r & 1 & 0.515 \\
& $p$ & & 0.000 \\
\hline SAS & r & & 1 \\
& & & \\
\hline
\end{tabular}

The average score of the students from the Internet Addiction Scale (IAS) was determined as 38.41 \pm 16.26 . With this score, the students participating in the research are classified in the "asymptomatic" group. In a study conducted by Sharma \& Sharma (2018) on university students, this point was determined as $31.99 \pm 18.20$. This difference is thought to be caused by cultural and socioeconomic factors. Considering the mean scores obtained from the IAS according to the gender of the participants, it was determined as $37.67 \pm 16.08$ for women and $40.82 \pm 16.67$ for men. A similar result to our study was obtained in the study of Anlayışlı\&Bulut Serin [12], and it was found $37.00 \pm 22.87$ in women and $40.97 \pm 18.82$ in men.

The average score of the students from the Smartphone Addiction Scale (SAS) was determined as $28.09 \pm 11.93$. With this score, it was concluded that the students participating in the study showed moderate smartphone addiction. When the distribution of the mean scores obtained from the SAS according to the genders was analysed, it was determined as $28.41 \pm 12.17$ for women and $27.01 \pm 11.05$ for men. A similar result to our study was found by Keskin and Friends [9], the mean score of the scale was $29.2 \pm 11.2$; $31.6 \pm 11.3$ in females and $26.9 \pm 10.8$ in males, and it was determined a significant difference between the groups $(p<0.05)$. Considering at the literature, there are differences in smartphone addiction scale scores according to gender. In general, women's smartphone addiction scale scores are higher than men, and this difference is not significant statistically $[13,9]$.

Although the use of smartphones makes life easier, it can also cause problems such as the length of use and because of these negative effects on daily life. Due to the direct proportionate between smart phone use and internet use, in our study, it was determined that there was a significant difference between students' daily internet use and smart phone addiction $(\mathrm{p}<0.05)$.

It was determined that there was a moderate, positive and significant $(\mathrm{r}=0.515 ; \mathrm{p}<0.05)$ relationship between internet addiction and smartphone addiction scales. In another study conducted by Tohumcu and friends [14], a highlevel, positive and significant relationship was determined between IAS and SAS $(r=0.72$; $\mathrm{p}<0.01)$. Existing such kind of relationship between smartphone addiction and internet addiction is considered as a normal situation. The continuous use of the two tools together and the high level of correlation as a result of the analysis for the two variables indicate this situation.

As a result, it was found that students' smart phone addiction scale and internet addiction scale mean scores were similar to previous studies. It has been determined that smartphone addiction is related to age, daily and weekly internet usage, and purpose of internet usage. It was determined that the students were in the "asymptomatic" group according to the average score obtained from internet addiction scale, and there was a significant difference between gender, monthly expenditure, daily and weekly internet usage and purpose of internet usage. According to these results, it can be said that there is a connection between smart phone usage and internet usage.

\section{Author Statements:}

- The authors declare that they have equal right on this paper.

- The authors declare that they have no known competing financial interests or personal relationships that could have appeared to influence the work reported in this paper

- The authors declare that they have nobody or no-company to acknowledge.

\section{References}

[1]. Duke, E., Montag, C. Internet addiction. "smartphone addiction and beyond: Initial insights on an emerging research topic and its relationship 
to internet addiction. 2017. Chapter 21, p:359, Switzerland, https://doi.org/10.1007/978-3-31946276-9.

[2]. YILDIRIM, Caglar; CORREIA, Ana-Paula. Exploring the dimensions of nomophobia: Development and validation of a self-reported questionnaire. Computers in Human Behavior, 2015, 49: 130-137.

[3]. GEZGIN, Deniz Mertkan; CAKIR, Ozlem; YILDIRIM, Soner. The relationship between levels of nomophobia prevalence and internet addiction among high school students: The factors influencing Nomophobia. International Journal of Research in Education and Science, 2018, 4.1: 215-225.

[4]. SecurEnvoy. (2012, February 16). $66 \%$ of the population suffer from Nomophobia the fear of being without their phone. Retrieved March 10, 2016, from https://www.securenvoy.com/blog/2012/02/16/66of-thepopulation-suffer-from-nomophobia-thefear-of-being-without-their-phone/

[5]. SIRAJ, Harlina Halizah, et al. Internet usage and academic performance: a study in a Malaysian public university. International Medical Journal, 2015, 22.2: 83-86.

[6]. SEKI, Tomokazu, et al. Relationship between internet addiction and depression among Japanese university students. Journal of affective disorders, 2019, 256: 668-672. https://doi.org/10.1016/j.jad.2019.06.055

[7]. BAYRAKTAR, F. İnternet kullanımının ergen gelişimindeki rolü (Yüksek lisans tezi, Ege Üniversitesi Sosyal Bilimler Enstitüsü, İzmir). 2001.

[8]. ADNAN, Müge; GEZGIN, Deniz Mertkan. Modern çağın yeni fobisi: Üniversite öğrencileri arasinda nomofobi prevalansı. 2016.

[9]. KESKIN, Tahir, et al. ÜNIVERSITE ÖĞRENCILERINDE AKILLI TELEFON KULLANIMI VE BAŞ AĞRISI İLIŞKİSİ. Adıyaman Üniversitesi Sağlık Bilimleri Dergisi, 2018, 4.2: 864-873. https://doi.org/10.30569/adiyamansaglik.428223

[10]. Sharma, A., Sharma, R. Internet addiction and psychological well-being among college students: a cross-sectional study from central india. J Family Med Prim Care. Jan-Feb 2018, 7.1:147-151. DOI: 10.4103/JFMPC.JFMPC_189_17

[11]. YOUNG, K. S. Internet addiction: The emergence of a new clinical disorder. Cyberpsycholoy \& Behavior, 1, 237-244. 1998.

[12]. ANLAYIŞLI, Cemre; SERIN, Nergüz Bulut. Lise öğrencilerinde internet bağımlılığı ve depresyonun cinsiyet, akademik başarı ve internete giriş süreleri açısından incelenmesi. Folklor/edebiyat, 2019, 25.97:

730-743. https://doi.org/10.22559/folklor.977

[13]. KWON, Min, et al. The smartphone addiction scale: development and validation of a short version for adolescents. PloS one, 2013, 8.12: e83558.

https://doi.org/10.1371/journal.pone.0083558
[14]. TOHUMCU, Mehmet Utku, et al. AKILLI TELEFON BAĞIMLILIĞI VE INTERNET BAĞIMLILIĞI İLE BENLIKK SAYGISI VE YALNIZLIK ARASINDAKİ İLIŞKININ İNCELENMESİ. Trakya University Journal of Social Science, 2019, 21.2. DOI: 10.26468/trakyasobed.545391

[15]. NOYAN, Cemal Onur, et al. Akıllı Telefon Bağımlılığı Ölçeğinin Kısa Formunun üniversite öğrencilerindeTürkçe geçerlilik ve güvenilirlik çalışması. Anatolian Journal of Psychiatry/Anadolu Psikiyatri Dergisi, 2015, 16. DOI: 10.5455/apd.176101 